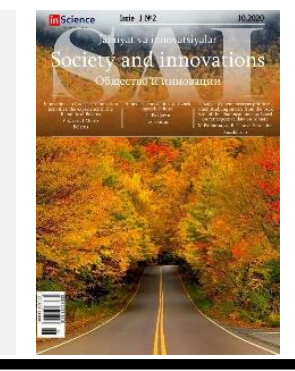

\title{
Organizational and legal measures for preparation and adoption of the international commercial arbitration act.
}

\section{Foziljon OTAKHONOV ${ }^{1}$}

Legislation and Parliamentary Research Institute under the Oliy Majlis of the Republic of Uzbekistan

\begin{tabular}{l} 
ARTICLE INFO \\
\hline Article history: \\
Received September 2020 \\
Received in revised form \\
15 September 2020 \\
Accepted 15 October 2020 \\
Available online \\
30 October 2020 \\
\\
\hline Keywords: \\
Arbitration \\
Foreign economic activity \\
Investment climate \\
Commercial dispute \\
Competent court, New York \\
Convention \\
Law
\end{tabular}

\begin{abstract}
This article is devoted to the analysis of the stages of implementation of organizational and legal measures for the preparation and adoption of the law on international commercial arbitration, as well as disclosure of the essence of international agreements and conventions in the field of international arbitration. The regulatory legal acts governing the establishment of international commercial arbitration are investigated and the corresponding conclusions are drawn.

2181-1415/C) 2020 in Science LLC.

This is an open access article under the Attribution 4.0 International (CC BY 4.0) license (https://creativecommons.org/licenses/by/4.0/deed.ru)
\end{abstract}

\section{Халқаро тижорат арбитражи тўғрисидаги қонунни тайёрлаш ва қабул қилиш бўйича ташкилий-хуқуқий чора- тадбирлар}

\begin{tabular}{l}
\hline Калит сўзлар: \\
Арбитраж \\
Ташқи иқтисодий фаолият \\
Инвестиция мухити \\
Тижорат низоси \\
Ваколатли суд \\
НьЮ-Йорк конвенцияси \\
Қонун
\end{tabular}

\begin{abstract}
АННОТАЦИЯ
Ушбу мақола халқаро тижорат арбитражи тўғрисидаги қонунни тайёрлаш ва қабул қилиш бўйича ташкилийхуқуқий тадбирларни амалга ошириш босқичларини тахлил қилишга, шунингдек халқаро арбитраж сохасидаги халқаро шартномалар ва конвенцияларнинг мохиятини очиб беришга бағишланган. Халқаро тижорат арбитражини яратишни тартибга солувчи норматив-хуқуқий хужжатлар ўрганилиб, тегишли хулосалар чиқарилган.
\end{abstract}

\footnotetext{
${ }^{1}$ DSc, Professor, Legislation and Parliamentary Research Institute under the Oliy Majlis of the Republic of Uzbekistan, Tashkent, Uzbekistan Email: haydarxon@mail.ru
} 


\title{
Организационно-правовые меры по подготовке и принятию закона о международном коммерческом арбитраже
}

\author{
Ключевые слова: \\ Арбитраж \\ Внешнеэкономическая \\ деятельность \\ Инвестиционный климат \\ Коммерческий спор \\ Кометентный суд \\ Нью-Йоркская конвенция \\ Закон.
}

\begin{abstract}
АННОТАЦИЯ

\begin{tabular}{l}
\multicolumn{1}{c}{ Настоящая } \\
статья посвящена анализу этапов \\
осуществления \\
подготовке и и принязационно-правовых мер покона ово о международном \\
коммерческом арбитраже, а также раскрытию сущности \\
международных соглашений и конвенции в области \\
международного арбитража. Исследованы нормативно- \\
правовые акты, регулирующие вопросы по созданию \\
международного коммерческого арбитража и сделаны \\
соответствующие выводы.
\end{tabular}
\end{abstract}

\section{INTRODUCTION}

In recent years, new Uzbekistan has consistently implemented measures aimed at creating the most favorable conditions for the accelerated development of small business and private entrepreneurship, further strengthening the legal mechanisms for protecting and guaranteeing the inviolability of private property, improving the investment climate and business environment.

The priority area of activity for states interested in attracting foreign investments, including direct ones, is the creation of a comfortable legal environment, improvement of laws and practice of their application. One of the most important objects for the application of such positive activity of the state should be the sphere of resolving international investment and commercial disputes. Authoritative, qualified arbitration forms a respectable image of the state in the international business environment, strengthens its reputation, which, in turn, leads to stabilization of the economy, including by creating a favorable investment climate [1, p.87].

The flexibility of the procedure, the guarantees of confidentiality to ensure maximum protection of trade secrets and business reputation, the possibility of choosing qualified specialists for the role of arbitrators - all this makes international commercial arbitration an attractive way of resolving conflicts for investors and international trade entities. That is why countries wishing to intensify the inflow of foreign investment into their economies need to develop the sphere of international commercial arbitration, both in legal and organizational terms.

This article will explain organizational and legal measures for preparation and adoption of the International Commercial Arbitration Act.

\section{METHODOLOGY}

In solving the tasks set in this article, general scientific and special methods of scientific knowledge were used: system, comparative-legal, analytical, logical-legal, etc.

The analysis of the norms of the international acts, legislation of the Republic of Uzbekistan and a number of foreign countries, some doctrinal works, scientific articles in the field of commercial law and arbitration was used as an empirical basis. 
Together, all these methods made it possible to ensure the reliability and validity of the research results in a scientific article to a certain extent.

\section{RESULTS OF THE STUDY}

The first and main step of any state to integrate into the global arbitration system is to comply with the main international agreements and membership in international institutions, regardless of ideological and political preferences. In this regard, purposeful and phased work is being carried out in our country to join international agreements in this area. In particular, Uzbekistan, on May 7, 1993, in order to stimulate foreign economic activity, provide internationally recognized guarantees and protect foreign investors in the Republic of Uzbekistan, joined the Convention on the Settlement of Investment Disputes between states and foreign persons (Washington, 1965), and on December 22, 1995 of the year to the New York Convention on the Recognition and Enforcement of Foreign Arbitration Awards of June 10, 1958.

The New York Convention enjoys great recognition, with 165 states [2] participating in it. It applies to awards made by arbitration tribunals in a country other than the state where recognition and enforcement is sought. Article III of the New York Convention imposes an obligation on all states parties to recognize and enforce arbitral awards.

As a party to the New York Convention, the Republic of Uzbekistan has obligations to recognize and enforce decisions of foreign arbitrations on its territory. At the same time, without such arbitration, the country becomes a "net importer" of such decisions, i.e. foreign arbitral awards are enforced in the country, and there are no own awards that can be enforced abroad.

When creating an international arbitration in Uzbekistan, its decisions will also be enforced on the territory of foreign states, which will ensure the protection of the rights of investors, including our country.

In addition, at present, due to the presence of problems with the recognition of decisions of economic courts of Uzbekistan abroad, business entities of our country are forced to determine by the body resolving the dispute on their foreign economic transactions, foreign arbitration (USA, France, Sweden, Russia, Ukraine, etc.) [3].

At the same time, participation in foreign arbitrations is associated with additional costs for our investors, which in some cases is a prerequisite for a forced refusal to participate in arbitration. In turn, this is the reason for ruling against Uzbek companies even in cases that have a positive perspective.

In this regard, the next step is the adoption of the Law of the Republic of Uzbekistan "On International Commercial Arbitration". It should be noted that the work on the preparation of the draft law has been carried out for more than twenty years, but without success. In recent years, the following measures have been intensively, consistently and systematically taken in this direction:

First. By the Decree of the President of the Republic of Uzbekistan dated June 19, 2017 №5087 "On measures to radically improve the system of state protection of the legitimate interests of business and further development of entrepreneurial activity", the Chamber of Commerce and Industry, together with the Ministries of Justice, Finance, Economy, and other interested ministries and departments to submit to the Cabinet of Ministers of the Republic of Uzbekistan a set of measures to create an international commercial arbitration court in the structure of the Chamber of Commerce and Industry 
of the Republic of Uzbekistan to ensure reliable protection of the rights and legitimate interests of foreign investors, as well as national companies in relations with foreign partners [4].

Second. On August 28, 2017, the Deputy Prime Minister of the Republic of Uzbekistan approved the Plan of Comprehensive Measures to establish an International Commercial Arbitration Court in the structure of the Chamber of Commerce and Industry of the Republic of Uzbekistan and formed a Working Group for the implementation of this Plan of Comprehensive Measures, which included representatives of the Ministries of Justice, Economy, Finance, Foreign trade, the chamber of commerce, legal scholars of Uzbekistan, Japan, Great Britain, arbitrators of international arbitration and lawyers.

Third. In pursuance of paragraph 21 of the "Program of measures to increase the country's investment attractiveness" approved by the Decree of the President of the Republic of Uzbekistan dated August 1, 2018 №5495 "On measures to radically improve the investment climate in the Republic of Uzbekistan" [6], a draft Law of the Republic of Uzbekistan "On international commercial arbitration" On the basis of the UNCITRAL Model Law - (UN Commission on International Trade Law) on international commercial arbitration [5].

The General Assembly, in its resolution, recommended that all States give due consideration to the Model Law on International Commercial Arbitration, bearing in mind the desirability of uniformity in the law on arbitration procedures and the specific needs of international commercial arbitration practice.

Through the preparation of this act by the UN Commission, which consisted of specialists from different states, international recognition of the Model Law was ensured, which resulted in the gradual adoption by more than 83 states of the world of 116 national laws on its basis.

The Model Law reflects a worldwide consensus on key aspects of international arbitration practice adopted in many States of the world, representing all regions and having different legal and economic systems. It also aims to assist states in reforming and updating their arbitration legislation in order to take into account the specific features and needs of international commercial arbitration.

Fourth. In recent years, the Legislative Chamber and the Senate of the Oliy Majlis, the Supreme Court, the Ministry of Justice, the Chamber of Commerce and Industry, the Tashkent State University of Law, the Association of Arbitration Courts of Uzbekistan, the Center for the Study of Legal Problems in conjunction with the United Nations Development Program in Uzbekistan, USAID, the German Society for International Cooperation, the French Embassy in Uzbekistan held more than ten international and republican scientific and practical conferences (seminars) dedicated to current problems and issues of the implementation of international commercial arbitration in Uzbekistan. In these events, the concept and the draft law on international commercial arbitration were also discussed and comments and suggestions were made on improving certain norms of the draft law [6]. In addition, scientific research in the field of international commercial arbitration has intensified, and books, articles by scientists and practitioners, including those abroad, have been published [7, p.650].

Fifth. At the meetings of the Expert Council of the Chamber of Commerce and Industry of the Republic of Uzbekistan on legal issues, experts discussed the draft Law of the Republic of Uzbekistan "On International Commercial Arbitration", finalized by the 
Working Group, taking into account the opinions and proposals of domestic and foreign experts and specialists in international commercial arbitration, including experts from Germany, Kazakhstan, United Arab Emirates, Russia, France, Ukraine and presented to the Cabinet of Ministers for submission to the Legislative Chamber of the Oliy Majlis of the Republic of Uzbekistan [8].

Sixth. The Legislative Chamber of the Oliy Majlis of the Republic of Uzbekistan initially adopted the Law of the Republic of Uzbekistan "On International Commercial Arbitration" on October 24, 2019 and was included in the agenda of the second plenary meeting of the Senate of the Oliy Majlis, held on February 28, 2020. Then the senators, noting the need to revise the law, rejected it. To resolve the issue, a conciliation commission of two chambers was created [9].

The Commission reviewed and revised the Law "On International Commercial Arbitration" taking into account the opinions and proposals of the members of both chambers. Then it was included in the agenda of the plenary session of the lower house. Some articles of the law were left unchanged, and some were supplemented by articles on immunity of arbitrators and other participants in arbitration proceedings, as well as on representation in arbitration proceedings, which are existing generally recognized principles in international practice. Also clarifications have been made to some articles of the law. After discussions, the law was adopted in the wording proposed by the conciliation commission and sent to the Senate [10].

Due to the fact that the revised Law meets international practice and the experience of developed countries, and also covers all stages of arbitration proceedings: from the conclusion of an arbitration agreement, determining the composition of the arbitral tribunal and resolving issues related to its competence and the scope of possible interference by competent courts, before the issues of recognition and enforcement of the arbitral award, at the seventh plenary session of the Senate of the Oliy Majlis, the Law of the Republic of Uzbekistan "On International Commercial Arbitration" was discussed and approved [11].

\section{CONCLUSIONS AND PROPOSALS}

In general, the adoption of the Law and the normal functioning of international commercial arbitration will allow:

first - the development of the institution of arbitration proceedings in Uzbekistan as one of the most important institutions of civil society, performing publicly significant functions and being an alternative way of resolving disputes;

the second is to create the necessary legal conditions to protect the rights and legitimate interests of business entities in the field of foreign economic activity and foreign investors;

the third is to ensure the reduction of the terms, costs of business entities and foreign investors when considering disputes arising from foreign economic transactions;

fourth, it will ensure an increase in the country's reputation in the region in dealing with controversial issues in international transactions;

fifth - the harmonious development of trade relations, improvement of the business environment and increasing the investment attractiveness of Uzbekistan; 
sixth - building the potential of national talented young professionals in the field of international commercial arbitration to protect the rights and legitimate interests of Uzbekistan in the international arena;

seventh - the establishment of the International Arbitration Center at the CCI of Uzbekistan as a regional center for resolving disputes with the participation of Central Asian countries.

\section{References}

1. Inshakova A.0. Legal mechanisms of the influence of international commercial arbitration on the formation of a successful investment image of the state // Bulletin of the Volgograd State University, ser. 5, Jurisprudence, 2014, No. 2, P.87 (in Russian).

2. Status of the tests: Convention on the Recognition and Enforcement of Foreign Arbitral Awards (New York, 1958) // https://uncitral.un.org/ru/texts/arbitration/ conventions / foreign arbitral awards/status2

3. The Ministry of Justice has officially commented on the Turkuaz case https://uz.sputniknews.ru/ trend / 20191115/12806836 / Ofitsialnoe-zayavlenieMinyust-po-delu-o-Turkuaz.html; Statistical data on the activities of the ICAC at the RF CCI in 2019 // https: // mkas. tpprf.ru/ru/Stat/page.php; The number of cases accepted for proceedings in 2019 // https://icac.org.ua/ru/statystyka-ta-praktyka/statystyka/

4. Collection of Legislation of the Republic of Uzbekistan, 2017, No. 25, Article 522.

5. Collection of Legislation of the Republic of Uzbekistan, 02.08.2018, No. 06/18/5495/1611, 14.08.2019, No. 06/19/5780/3559, 14.12.2019, No. 06/19 / 5894 / 4161) https://www.uncitral.org/pdf/russian/texts/arbitration/ml-arb/07-870 00 Ebook.pdf.

6. Dedicated to the development of arbitration in Uzbekistan // http://senat.uz/ru / lists / view / 468; International commercial arbitration as a form of entrepreneurship protection // http://www.chamber.uz/ru/news/1490

7. Law and practice of international arbitraion in the CIS region. - Printed in the United Kindom .: Wolters Kluwer, 2017 .-- 650 p. (co-authors F. Otakhonov, A. Umirdinov, M. Karaketov and others); Otakhonov F., Sayfullaev S. International arbitration of disputes in the Convention on Reconciliation and Arbitration within the OSCE // J. 'Economy and Law', 2002. No. 5. - pp. 88-90 (in Russian); Materials of the International Scientific and Practical Conference "International Commercial Arbitration in the Context of Judicial and Legal Reform” October 28, 2009 -T .: “Chashma Print, 2010.- P.253-259 (in Russian); Otaxonov F. International Commercial Arbitration Court and local documents of legal entities - T .: Institute of Philosophy and Law, 2011. - 160 p. (in Uzbek); Otaxonov F. The International Commercial Arbitration Court is a non-governmental body for alternative dispute resolution // "Actual problems of civil litigation in the context of judicial reform materials of the scientific-practical conference dedicated to the 80th anniversary of Doctor of Law, Professor Sh.Sh. Shorahmetov. -T .: TDYuI, 2011.-B. 31-37 (in Uzbek); Otaxonov F.X. Organizational and legal measures for the development of international commercial arbitration in Uzbekistan - on the website of the CIS Arbitration Forum - Russia- and CISrelated International Dispute Resolution //http://cisarbitration.com/2014/02/14/arbitraj-v-uzbekistane /; The text of the draft Law of the Republic of Uzbekistan "On International Commercial Arbitration". (project December 29, 2009) // International Commercial Arbitration-Sbornik Materialov.- T .: 
Adolat, 2012, P.277-295 (in Uzbek); Rustambekov I.R. Some practical aspects of resolving investment disputes in international arbitration (on the example of Uzbekistan) // Collection of materials of the XVI International scientific-practical conference "Theoretical aspects of jurisprudence and issues of law enforcement". - No. 10 (16). Part 1. - M., Ed. "Internauka", 2018. - S. 54-58 (in Russian); Otakhonov F.Kh. Prospects for the development of international commercial arbitration in Uzbekistan file: /// C: /Users/f.otaxonov/Desktop/20-\%20RND 2018_10-12_pp58-61.pdf (Moldova) (in Russian); Otakhonov F.Kh. Legal framework for the recognition and enforcement of foreign arbitral awards in Uzbekistan // "Arbitration in the Kyrgyz Republic: modern challenges and solutions (to the 60th anniversary of the UN Convention on the Recognition and Enforcement of Foreign Arbitral Awards)" - Annual collection of articles of the International Arbitration court at the Chamber of Commerce and Industry of the Kyrgyz Republic 2/2018. Bishkek, 2019. P.44-54 (in Russian).

8. International "round table" jointly with the International law firm "Merritz" // http://chamber.uz/ru/news/3224.

9. Ten more steps in rulemaking //http://parliament.gov.uz/ru/events / other / 31649 /? Sphrase_id = 6647733; Why has the law been removed from the agenda? // http://parliament.gov.uz/ru/events / chamber / 30528 /? Sphrase_id $=6647733$.

10. Senators rejected the Law of the Republic of Uzbekistan "On International Commercial Arbitration" // http://senat.uz/ru/lists/view/1142. Adopted after rejection in the wording of the conciliation commission //http://parliament.gov.uz/ru/events/chamber / 31663 /? Sphraseid $=6647733$.

11. The Law "On International Commercial Arbitration" was approved //http://senat.uz/ru/-lists/view/1831. 